\title{
Graft modification of carboxymethyl chitosan with styrene and its biological applications
}

\author{
Omayma F. Abdel GawadD
}

\begin{abstract}
Background: Carboxymethyl chitosan (CMCh) is a water-soluble chitosan derivative and it has been widely used in biomedical applications due to its unique properties. Modification of CMCh by graft copolymerization with different monomers is done in order to enhance its applications.

Results: Graft copolymerization of styrene (S) onto CMCh using ammonium persulfate (APS) as initiator was successfully done with optimization of grafting parameters. The new materials were prepared in nano size. The antibacterial activities against Streptococcus pneumonia (RCMB 010010), Staphylococcus aureus (RCMB 010028) as Gram-positive and Escherichia coli (RCMB 010052) as Gram-negative bacteria and antifungal activity against Aspergillus fumigates (RCMB 02568), Candida albicans (RCMB 05036), Syncephalastrum racemosum (RCMB 05922), and Geotricum candidum (RCMB 05097) were examined using the diffusion agar technique. Also, the cytotoxicity effect against mammalian cell lines (MCF-7cells (human breast cancer) and HTC-116 (colon carcinoma)) was evaluated.

Conclusions: The obtained data proved that grafted carboxymethyl chitosan with styrene (CMCh-g-S) shows better antimicrobial activities, while parent carboxymethyl chitosan showed higher activity than new grafted materials. Also the nano scaled grafted CMCh showed higher activities than grafted carboxymetyl chitosan in macro scale.
\end{abstract}

Keywords: Carboxymethyl chitosan, Grafting, Antimicrobial activity, Cytotoxicity evaluation

\section{Background}

Chitosan [poly-( $\beta$-1/4)-2-amino-2-deoxy-D-glucopyranose] is a corporate name because of a group concerning partially and completely deacetylated chitin compounds [34]. Due to its special biological characteristics, consisting of biodegradability and nontoxicity, much applications have been found, either individual and blended with other natural polymers (starch, gelatin, alginates), in the food, pharmaceutical, textile, agriculture, water treatment, and beauty industries $[4,5,18,24,30,38]$. Since chitosan dissolves in diluted acid solutions, films can be formed by casting or dipping, giving dense and porous structure $[6,8]$. Films of chitosan are considered as biofunctional substance, good tolerated by living tissues, particularly applicable as edible coatings to extend shelf-life and maintain quality of fresh foods [7]. For

Correspondence: Omayma2013@hotmail.com

Department of Chemistry, Faculty of Science, Beni-Suef University, Beni-Suef, Egypt biomedical field, chitosan films have been examined as medicinal wound dressing and as scaffolds for tissues and bone engineering (Liu et al. 2001). Furthermore, the existence of reactive functional groups in chitosan can help in chemical derivatization allowing the modification of mechanical and solubility properties [9] which increase its biocompatibility. The potent application regarding chitosan is hindered by its restricted solubility in aqueous media. Thus, chitosan is chemically modified so as to enhance its process ability, solubility, antimicrobial activity, and its ability to interact including other components $[19,20]$. Introducing a carboxymethyl group is the nearly effective method of increasing the solubility of chitosan at neutral and alkaline $\mathrm{pH}$ media without affecting other essential characteristics. O-carboxymethyl chitosan (CMCh) is an amphiprotic ether derivative of chitosan, containing each the $-\mathrm{COOH}$ longevity and $-\mathrm{NH}_{2}$ groups into the molecule, and possesses nontoxicity, biodegradability, biocompatibility, antimicrobial activity, and has therefore acquired big interest into
Springer Open

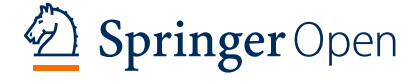

(c) The Author(s). 2020 Open Access This article is distributed under the terms of the Creative Commons Attribution 4.0 International License (http://creativecommons.org/licenses/by/4.0/), which permits unrestricted use, distribution, and reproduction in any medium, provided you give appropriate credit to the original author(s) and the source, provide a link to the Creative Commons license, and indicate if changes were made. 
biomedical applications $[19,20,28])$ Chemical modification [33] concerning $\mathrm{CMCh}$ or physical mixing along every other polymer [14] has been broadly studied to obtain materials including novel properties.

Chemical modification regarding biopolymers is an important aspect which continues to obtain significant attention. One regarding the applications is the build regarding the grafting copolymers by free radical mechanism. "Grafting onto" technique was employed to graft vinyl monomers onto chitosan the usage of distinctive initiators. Poly ( $N$-vinyl imidazole) was grafted onto carboxymethyl chitosan using potassium persulfate initiator [31]. Polystyrene comes after polyolefins, the most common polymer in both industry and everyday life [22]. This is due to its low cost, easy production, and acceptable properties such as a good balance of toughness, rigidity, and transparency. Styrene successfully grafted onto starch with high efficiency [32]. It is also grafted onto chitin using ammonium persulfate (APS) [2] and efficiently grafted onto chitosan using APS as initiator [1]. In the previous grafting of styrene, we can notice that there is no application for the prepared new materials, so here in this study, the novelty is trying to prepare a new material with new applications especially in microbial and medical fields.

In the present work, styrene is grafted onto carboxymethyl chitosan using ammonium persulfate as initiator in order to improve the applications of the carboxymethyl chitosan. The variables among grafting reaction were investigated which includes initiator and monomer concentrations, reaction time, and temperature concerning the polymerization process. The new material was prepared within nano scale. The prepared materials had been characterized by means of FT-IR, X-ray diffraction, thermal analyses and scanning, and transmitting electron microscope. Their antibacterial activities toward some Gram-positive and Gram-negative bacteria then toward some fungi had been also examined using the diffusion agar technique. Also, the cytotoxicity against human cell lines (MCF-7 cells (human breast cancer) and HCT-116 (colon carcinoma)) was evaluated.

\section{Methods}

\subsection{Materials}

Chitosan (Bio Basic Canada INC) degree of deacetylation is $96 \%$. Styrene was purchased from Sigma-Aldrich; ammonium persulfate (Oxford Laboratory), sodium hydroxide (Oxford laboratory Mumbai-400 002, India), monochloroacetic acid (ADWIC laboratory chemicals), hydrochloric acid, nitric acid, acetic acid, and methanol were obtained from Piochem. Company, Egypt. All the microorganisms were obtained from RCMB: Regional Center For Mycology And Biotechnology Antimicrobial unit test organisms, Egypt. Dimethyl sulfoxide (DMSO), crystal violet, and Trypan blue dye were purchased from Sigma (St. Louis, Mo., USA). Fetal bovine serum, Dulbecco's modified Eagle's medium DMEM, Roswell Park Memorial Medium RPMI-1640, 4-(2-hydroxyethyl)-1piperazineethanesulfonic acid HEPES buffer solution, Lglutamine, gentamycin, and $0.25 \%$ Trypsin-EDTA were purchased from Lonza, Switzerland.

\subsection{Experimental}

\subsubsection{Synthesis of O-CMCh}

$\mathrm{CMCh}$ was prepared in step with the technique defined through Chen and Park method [10] through stirring $5 \mathrm{~g}$ of chitosan in $100 \mathrm{~mL}$ of $20 \% \mathrm{NaOH}(\mathrm{w} / \mathrm{v})$ for $15 \mathrm{~min}$. Then $15 \mathrm{~g}$ of monochloroacetic acid was introduced portion wisely to the reaction medium and stirring was persevered for $2 \mathrm{~h}$ at $40{ }^{\circ} \mathrm{C}$. The reaction combination become then neutralized with $10 \%$ acetic acid, poured into an extra of $70 \%$ methanol, filtered, and washed with methanol. The produced CMCh sodium salt was dried in a vacuum oven at $55{ }^{\circ} \mathrm{C}$ for $8 \mathrm{~h}$. The sodium salt of $\mathrm{CMCh}$ was then acidified with a methanol solution containing nitric acid; the excess acid was then eliminated by way of washing with a methanol-water solution until acid loose. The product was vacuum dried at $50{ }^{\circ} \mathrm{C}$ (Scheme 1).

\subsubsection{Synthesis of CMCh-g-polystyrene}

Grafting technique was performed at various reaction conditions. $1 \mathrm{~g}$ CMCh was dissolved in $\mathrm{HCl}$ (aq) (100 $\mathrm{mL}, \quad 0.1 \mathrm{M})$ and stirred with glass rod to attain homogenous solution. The solution was mixed with APS $(0.2-0.8 \mathrm{~g})$ and stirred for $40 \mathrm{~min}$ as pre-interacting time. Various concentrations of the monomer (styrene) were added to the reaction medium drop wisely. The polymerization reaction was then heated at temperature extent then allowed to proceed for the targeted period. When the polymerization time is reached, methanol is introduced to stop the polymerization process. Then filtration and drying was done in vacuum oven at $40{ }^{\circ} \mathrm{C}$. The dried sample was then extracted in a soxhelt apparatus for $48 \mathrm{~h}$ to remove any polystyrene present. The produced polymer was filtered and dried at $50{ }^{\circ} \mathrm{C}$ in vacuum oven.

The graft yield G\% and grafting efficiency GE\% were calculated according to the following Eqs. 1 and 2:

$$
\begin{aligned}
& \operatorname{Graft} \text { yield }(\mathrm{G} \%)=\left[\left(\mathrm{W}_{1}-\mathrm{W}_{0}\right) / \mathrm{W}_{0}\right] \times 100 \\
& \text { Grafting efficiency }(\mathrm{GE} \%)=\left(\mathrm{W}_{1} / \mathrm{W}_{2}\right) \times 100
\end{aligned}
$$

where $W_{0}, W_{1}$ are the weights of initial matrix and grafted matrix (i.e., weight of the product after extraction), respectively. Whereas $W_{2}$ is the crude product before extraction [26]. 


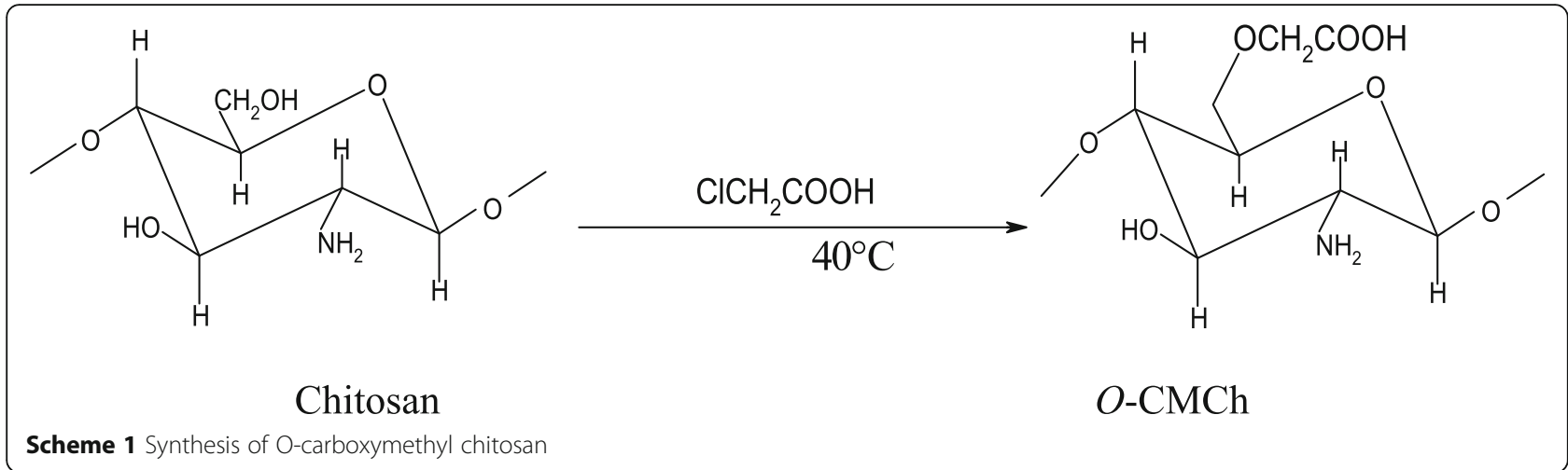

\subsubsection{Preparation of $\mathrm{CMCh}$-g-polystyrene in nano size}

CMCh-g-polystyrene mechanically milled among strength harmony locally created by means of Photon Scientific Company, Egypt. The apparatus has a cylindrical stainless steel tank of internal diameter $15 \mathrm{~cm}$. The grinding balls instituted of stainless steel are $6 \mathrm{~mm}$ and $15 \mathrm{~mm}$ in diameter. The CMCh-g-polystyrene polymer allowed to keep milled at $500 \mathrm{rpm}$ for $10 \mathrm{~h}$.

\subsubsection{Antimicrobial measurements}

The disks of Whatman filter paper had been prepared together with standard size (50 $\mathrm{mm}$ diameter) and kept into ten screw capped broad mouthed containers for sterilization. These bottles are kept between hot air oven at a temperature of about $150{ }^{\circ} \mathrm{C}$. Then, the standard sterilized filter paper disks impregnated together with a solution concerning the check composite in DMSO $(1 \mathrm{mg} /$ $\mathrm{mL}$ ) had been placed on nutrient agar plate seeded including the suitable test life between triplicates. Standard conditions concerning $106 \mathrm{CFU} / \mathrm{mL}$ (colony forming $\mathrm{U} / \mathrm{mL}$ ) then $104 \mathrm{CFU} / \mathrm{mL}$ had been used for antibacterial and antifungal assay, respectively. Durability Petri dishes $(9 \mathrm{~cm}$ of diameter) have been used and two disks over filter paper had been inoculated into every plate. The utilized test organisms were Streptococcus pneumonia (RCMB 010010) and Staphylococcus aureus (RCMB permanency 010028) as much examples regarding Gram-positive bacteria and Escherichia coli (RCMB 010052) as much example concerning Gram-negative bacteria. They were also evaluated because of their in vitro antifungal potential towards Aspergillus fumigates (RCMB 02568), Geotricum candidum (RCMB 05097), Syncephalastrum racemosum (RCMB 05922), and Candida albicans (RCMB 05036). Ampicillin, Ciprofloxacin, then Amphotericin B have been used as reference drugs against Gram-positive bacteria, Gramnegative bacteria, and fungi, respectively; all the microorganisms were obtained from RCMB: Regional Center For Mycology And Biotechnology Antimicrobial unit test organisms. DMSO individual was used as like monitoring at the same abovementioned concentration and during this, no visible alternate within bacterial growth. The incubation temperature was $37{ }^{\circ} \mathrm{C}$ for 24 and $48 \mathrm{~h}$ for bacteria and for fungi respectively. The derivatives up to expectation showed extensive growth inhibition zones, and the use of the double serial series technique has been similarly evaluated for their minimum inhibitory concentration (MIC).

\subsubsection{Minimum inhibitory concentration} measurements The determination of antibacterial and antifungal activity have been performed with the aid of using the micro dilution susceptibility test in MullerHinton Broth (Oxoid) and Sabouraud Liquid Medium (Oxoid) were used respectively. Stock solutions concerning the examined samples had been organized within DMSO. Stock solutions were mixed together with standard technique broth (Difco) to form consecutive twofold dilutions of the broth containing about $106 \mathrm{CFU} /$ $\mathrm{mL}$ of test microorganism and introduced to each well of 96-well microtiter plate. Incubation for sealed microplater at $37{ }^{\circ} \mathrm{C}$ for $24 \mathrm{~h}$ for antibacterial activity and at the equal temperature for $48 \mathrm{~h}$ for antifungal activity in a wet chamber. By the ending of incubation time, the minimal inhibitory concentrations (MICs) evaluations were recorded as the lowest concentrations of the material that had no apparent turbidity. Control tests with DMSO and uninoculated media were run in equal to the test materials under the same conditions.

\subsubsection{Cytotoxicity assay}

2.2.5.1 Cell culture MCF-7 cells (human breast cancer) cell line and HCT-116 (colon carcinoma) were brought from VACSERA Tissue Culture Unit, Agouza, Giza. The cells were multiply in Dulbecco`s modified Eagle`s medium (DMEM) (purchased from Lonza) supplemented with $10 \%$ heat-inactivated fetal bovine serum, $1 \%$ L-glutamine, HEPES buffer, and $50 \mu \mathrm{g} / \mathrm{mL}$ gentamycin. All cells were kept at $37^{\circ} \mathrm{C}$ in a moisten atmosphere with $5 \% \mathrm{CO}_{2}$ and were sub cultured two times a week. 
2.2.5.2 Cytotoxicity assay Cytotoxicity estimation using viability assay: For cytotoxicity assay, the cells were seeded within 96-well plate at a cell concentration of $1 \times$ 104 cells through well between $100 \mu \mathrm{L}$ of growth medium. The medium which contain a range of concentrations of the tested sample was used to be added after $24 \mathrm{~h}$ of seeding. Permanency addition of a serial twofold dilutions of the tested sample had been introduced according to confluent cell monolayers distributed among 96-well, flat-bottomed microtiter plates (Falcon, NJ, USA) using a multichannel pipette. Incubation of the microtiter plates at $37{ }^{\circ} \mathrm{C}$ in a moisten incubator along $5 \% \mathrm{CO}_{2}$ was done for a duration of $48 \mathrm{~h}$. For each concentration, three wells were used. Control cells also incubated without any tested sample with or without DMSO. The title percentage on DMSO existing into the wells (maximal $0.1 \%$ ) was not affect by the experiment. After incubation time of the cells for at $37{ }^{\circ} \mathrm{C}$, different concentrations of the tested sample were added, and then incubated for $24 \mathrm{~h}$ then viable cells generated was evaluated with assistance of a colorimetric process [27].

After the incubation time is reached, media were aspirated and the crystal violet solution (1\%) was used to be introduced to each cell properly for at least $30 \mathrm{~min}$. The stain was removed then the plates had been cleaned by using tap water until the entire extra stain is removed. Glacial acetic acid (30\%) was afterward introduced to entire wells and combined thoroughly, and then the absorbance of the plates has been measured since gently shaken on microplate reader (TECAN, Inc. Switzerland), with the use of a test wavelength of $490 \mathrm{~nm}$. Treated samples were compared with the cell limit in the absence of the tested compounds. All experiments have been carried out three times. The cell cytotoxic impact of every tested compound was calculated. The optical density used to be measured together with the microplate reader (SunRise, TECAN, Inc, USA) to determine the range of viable cells and the proportion of viability was calculated as [1-(ODt/ODc)] $\times$ $100 \%$ where ODt is the mean optical density of wells treated together with the tested sample and ODc is the relation among surviving cells and medicine concentration is plotted to reach the survival curve about every tumor cell line after cure with the designated compound. The $50 \%$ inhibitory concentration (IC50), the concentration required to motivate toxic effects in $50 \%$ of intact cells, used to be estimated beside graphic plots of the dose response curve for each concentration using Graphpad Prism software (San Diego, CA. USA) [16, 27].

\section{Instrumentations}

\subsection{Infrared spectroscopy}

FT-IR spectra were recorded in ATR discs on (VERTEX 70 FT-IR spectrometer) at room temperature within the wave number range of $4000-600 \mathrm{~cm}^{-1}$.

\subsection{Scanning electron microscope}

Scanning electron microscopy was (SEM) images were obtained using JEOL (JSM-5200). Samples were prepared by putting a small portion of film on carbon tube on a stub, which was coated with thin coat of gold.

\subsection{Transmission electron microscopy}

Micrographs of the prepared CMCh-g-S macro and nano size were taken using a JEM-100S transmission electron microscope (TEM, Jeol, Tokyo, Japan). The pictures of different areas were captured at adjustable magnifications which identify the morphology and particles size.

\subsection{X-ray diffraction}

The analysis was done on 2020964 PANalytical Empyrean which is a method that uniquely provides phase characterization (e.g., graphite or diamond), along with phase quantification and crystallite size.

\subsection{Thermogravimetric analysis}

The analysis was done on TGA-50H thermogravimetric analyzer. Samples were heated from 10 to $600{ }^{\circ} \mathrm{C}$ in a platinum pan with a heating rate of $10{ }^{\circ} \mathrm{C} \mathrm{min}{ }^{-1}$ under $\mathrm{N}_{2}$ atmosphere with flow rate of $25 \mathrm{~mL} \mathrm{~min}^{-1}$.

\section{Results}

\subsection{Effect of the reaction parameters on the graft efficiency}

\subsubsection{Effect of initiator concentration}

Figure 1 shows the impact concerning initiator concentration (APS) on the graft copolymerization of styrene onto $\mathrm{CMCh}$ with the aid of maintaining other reaction conditions constant.

\subsubsection{Effect of monomer (styrene) concentration}

Figure 2 shows the impact of weight ratio of $\mathrm{CMCh}$ : styrene.

\subsubsection{Effect of the reaction temperature}

Figure 3 shows the grafting that was carried out at different temperatures $\left(50-80^{\circ} \mathrm{C}\right)$ and at 1:3 CMCh:styrene weight ratio.

\subsubsection{Effect of reaction time}

Figure 4 shows the effect of time on graft percentage (\% G), and grafting efficiency.

\subsection{Characterization}

4.2.1 FT-IR

Figure 5 shows the spectra of chitosan which presented strong peaks at $1155,1073,1030$, and $895 \mathrm{~cm}^{-1}$. 


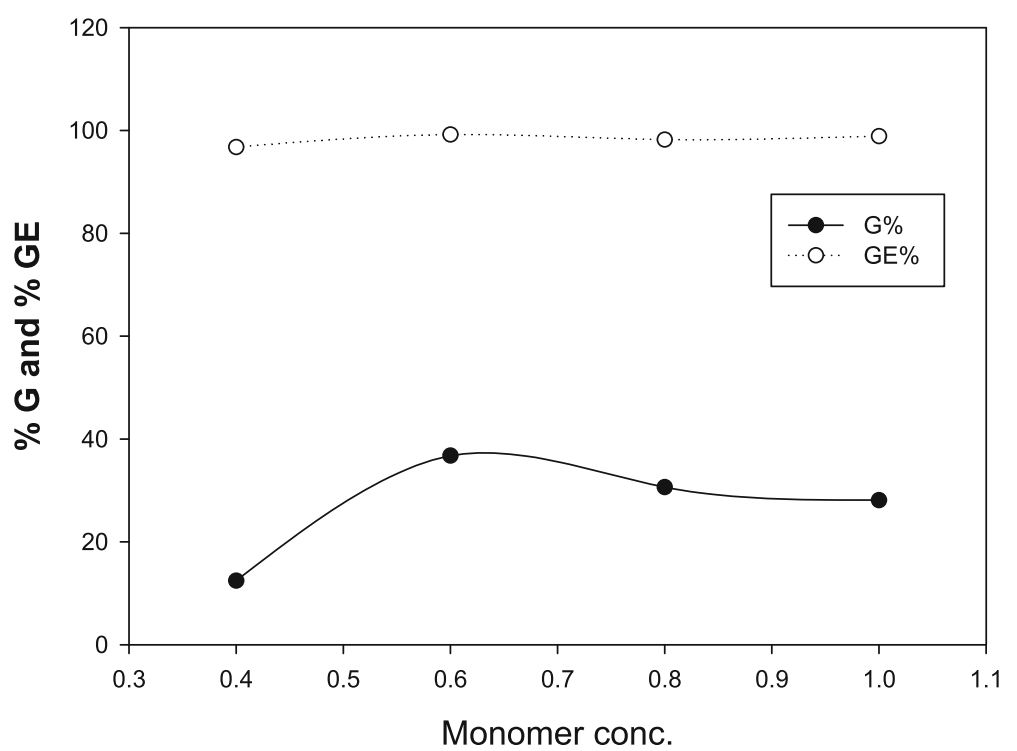

Fig. 1 Effect of initiator concentration APS on grafting percentage (\%G) and grafting efficiency (\%GE) (Reaction conditions: $1 \mathrm{~g}$ CMCh, 3 M styrene, time $2 \mathrm{~h}$, temperature $60^{\circ} \mathrm{C}$ )

\subsubsection{X-ray diffraction}

Figure 6 shows that the grafting decreases intensity of the diffraction peaks.

\subsubsection{Scanning and transmission electron microscopes} Figure 7 shows SEM photography of CMCh, CMCh-g-S, and $\mathrm{CMCh}-\mathrm{g}-\mathrm{S}$ nano at optimum grafting conditions.

Figure 8 shows TEM photography of $\mathrm{CMCh}$, CMCh-g$\mathrm{S}$, and $\mathrm{CMCh}-\mathrm{g}-\mathrm{S}$ nano at optimum grafting conditions.

\subsubsection{Thermal analysis}

Figure 9 shows thermal analysis of $\mathrm{CMCh}, \mathrm{CMCh}-\mathrm{g}-\mathrm{S}$, and $\mathrm{CMCh}-\mathrm{g}-\mathrm{S}$ nano under $\mathrm{N}_{2}$ atmosphere.

\subsection{Antimicrobial activity} 4.3.1 Antibacterial activity

The results of antibacterial activity concerning the CMCh and grafted CMCh using diffusion agar method are listed in Table 1.

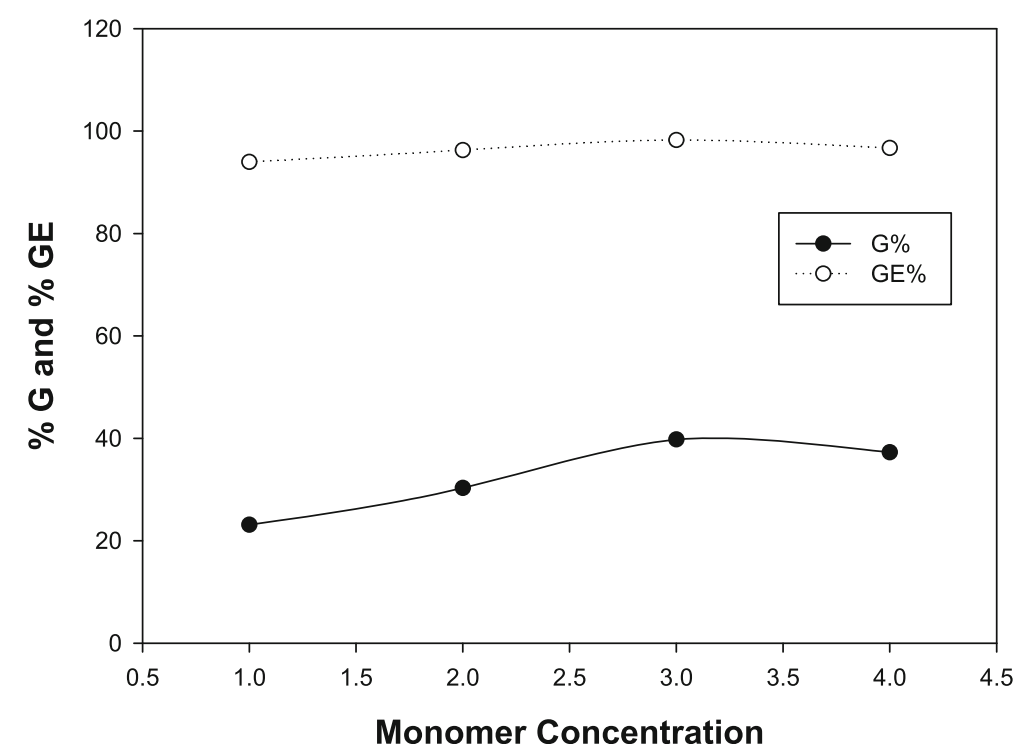

Fig. 2 Effect of monomer concentration on grafting percentage (\%G) and grafting efficiency (\%GE) (Reaction conditions: $1 \mathrm{~g}$ CMCh, [APS]=0.6 g, time $2 \mathrm{~h}$, temperature $60^{\circ} \mathrm{C}$ ) 


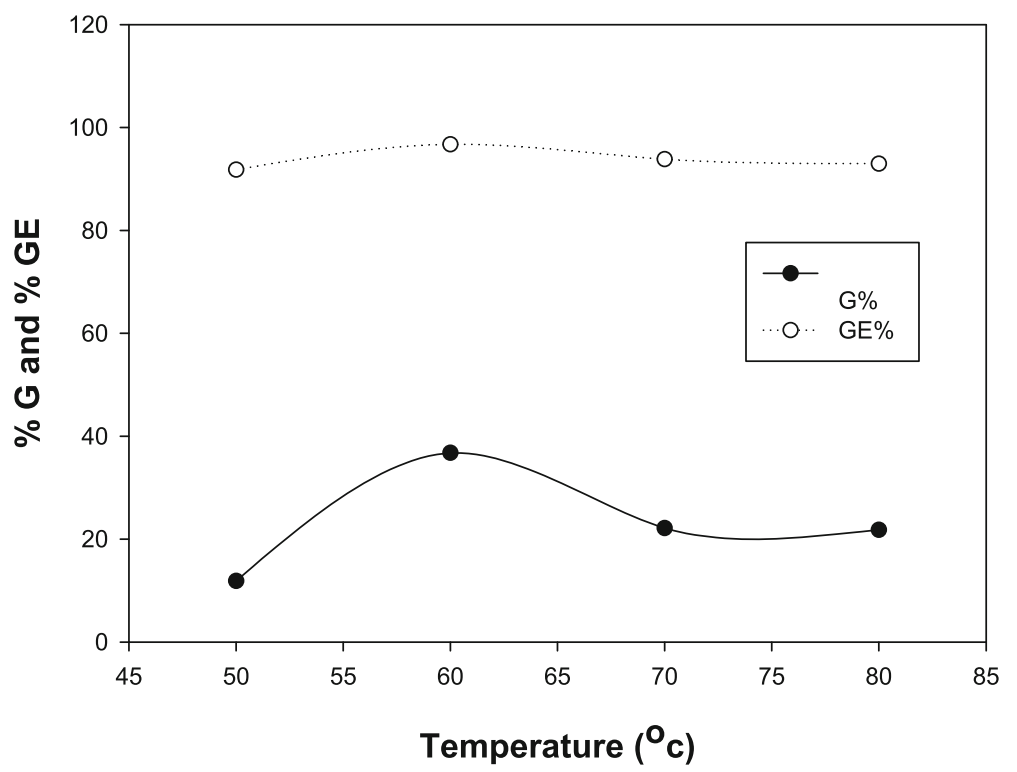

Fig. 3 Effect of reaction temperature on grafting percentage (\%G) and grafting efficiency (\%GE) (Reaction conditions: $1 \mathrm{~g}$ CMCh, 3 M styrene, time $2 \mathrm{~h},[\mathrm{APA}]=0.6 \mathrm{~g}$

\subsubsection{Antifungal activity}

The antifungal activities of $\mathrm{CMCh}$ and $\mathrm{CMCh}-\mathrm{g}-\mathrm{S}$ in macro and nano size against A. fumigatus (RCMB 02568), G. candidum (RCMB 05097), S. racemosum (RCMB 05922), and C. albicans (RCMB 05031) are shown within Table 2.

\subsection{Cytotoxicity}

Figure 10 shows the viability of MC-7 cell line after $24 \mathrm{~h}$ exposure to $\mathrm{CMCh}$, CMCh-g-S, and CMCh-g-S nano.

Table 3 shows the cytotoxicity effect of $\mathrm{CMCh}, \mathrm{CMCh}-$ g-S, and CMCh-g-S nano against MCH-7 cell line .

Figure 11 shows the viability of HTC-116 cell line after 24-h exposure to CMCh, CMCh-g-S, and CMCh-g-S nano.

Table 4 shows the cytotoxicity effect of $\mathrm{CMCh}, \mathrm{CMCh}-$ $\mathrm{g}-\mathrm{S}$, and $\mathrm{CMCh}-\mathrm{g}-\mathrm{S}$ nano against HTC-116 cell line

\section{Discussion}

Free radical polymerization started by using the generation of free radical species among the availability of vinyl monomer(s) [23]. The active sites in the reaction are typically made by way of addition of initiator. It is proved that water-soluble initiator(s) such as potassium persulfate may decompose thermally under appropriate temperature, to provide a pair of reactive species $\left(\mathrm{SO}^{-}\right)$[3]. Some of these effective species should then diffused out of the solvent cage and attack the most easily available hydrogen atom on the major polymer producing reactive site(s) on the major polymer, which can be applied in grafting vinyl monomer onto the main backbone of any cellulose- like polymer [2, 3].The formation of carboxymethyl chitosan macroradicals and preparation of the grafting copolymer are shown in Scheme 2.

\subsection{Effect of the reaction parameters on the graft efficiency}

\subsubsection{Effect of initiator concentration}

The impact concerning initiator concentration (APS) on the graft copolymerization of styrene onto $\mathrm{CMCh}$ with the aid of maintaining other reaction conditions constant is showed in Fig. 1. Both graft percentage G\% and grafting efficiency GE\% permanency showed an increase together with increasing durability initiator concentration. The increase concerning grafting percentage may additionally be ascribed to the enlarge concerning macroradicals generated with the aid of the attack of more APS on the saccharide unit of CMCh and therefore, the greater active sites of $\mathrm{CMCh}$ reacting with styrene, which then lowered above $0.6 \mathrm{~g}$. This could be due to the formation of extra initiating radicals that ought to develop quickly termination of the developing radical which raise homopolymerization of styrene [2]. The maximum yield was determined to be $36.77 \%$ at initiator concentration $0.6 \mathrm{~g}$ in this grafting reaction at CMCh:styrene $1: 3$ weight ratio, $60^{\circ} \mathrm{C}$, for $2 \mathrm{~h}$.

\subsubsection{Effect of monomer (styrene) concentration}

The impact of weight ratio of CMCh:styrene is showed in Fig. 2. The grafting percentage G\% and grafting efficiency GE\% had been observed to increase with increasing styrene concentration. The most grafting yield was observed to be $39.77 \%$ at $1: 3 \mathrm{CMCh}$ styrene weight ratio. 


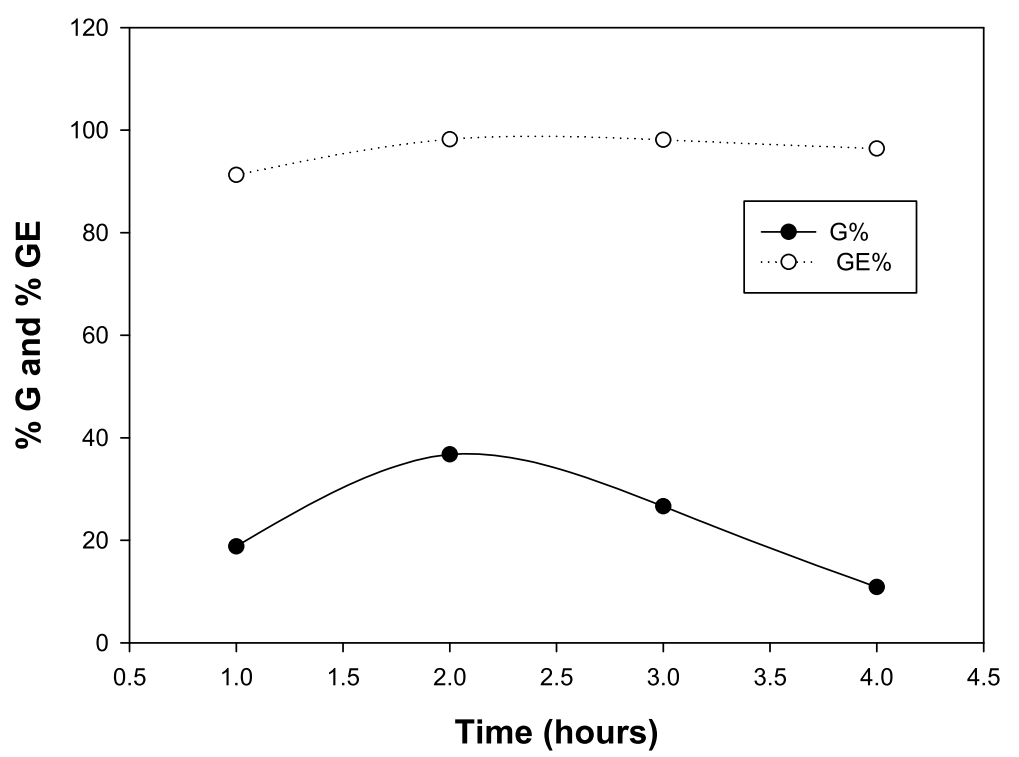

Fig. 4 Effect time on graft percentage (\%G) and grafting efficiency (\%GE) (Reaction conditions: $1 \mathrm{~g}$ CMCh, 3 M styrene, [APS]=0.6 g, temperature $60^{\circ} \mathrm{C}$ )
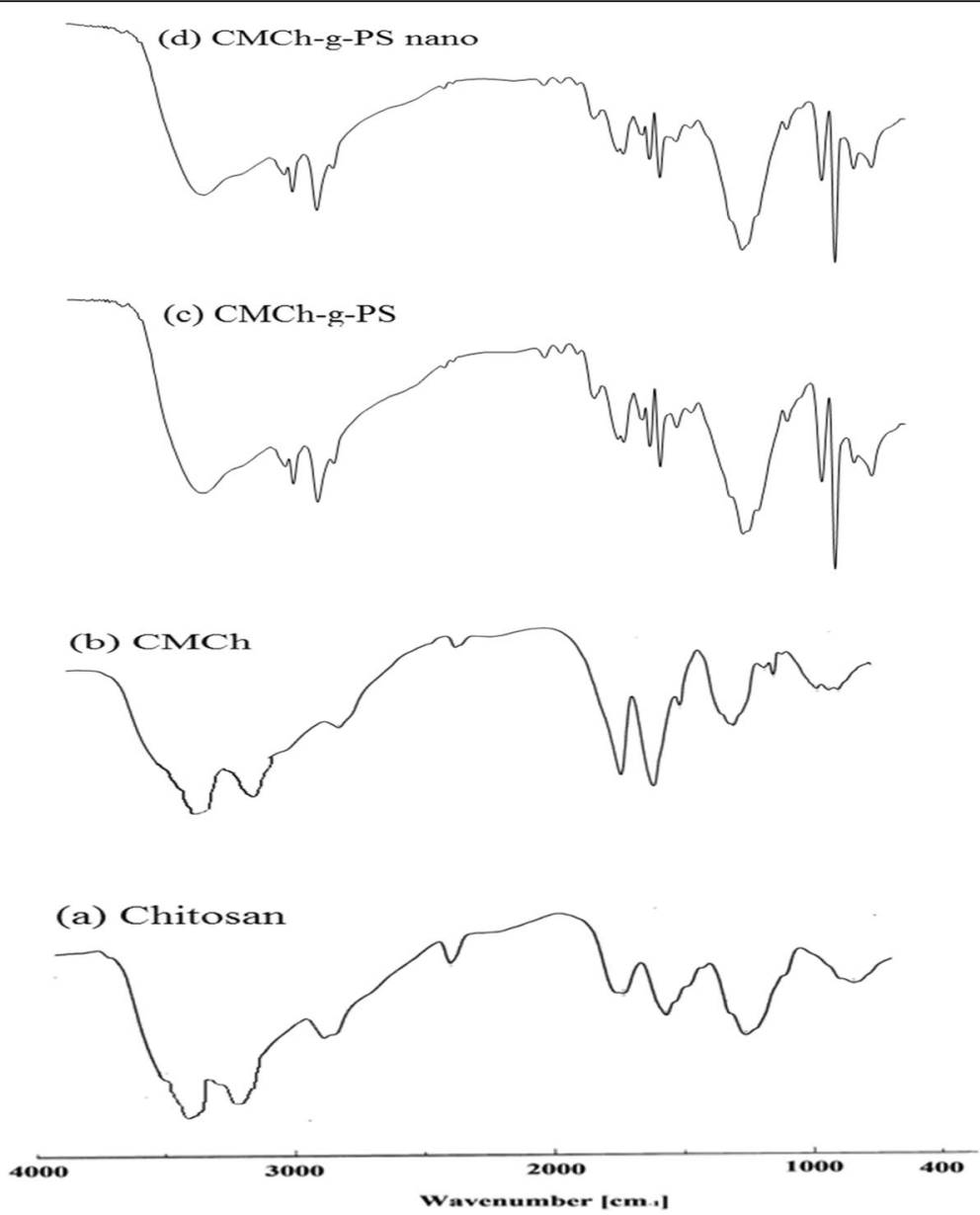

Fig. 5 FTIR spectra of (a) chitosan (b) CMCh (c) CMCh-g-Sty copolymer (d) CMCh-g-S nano at optimum grafting conditions 

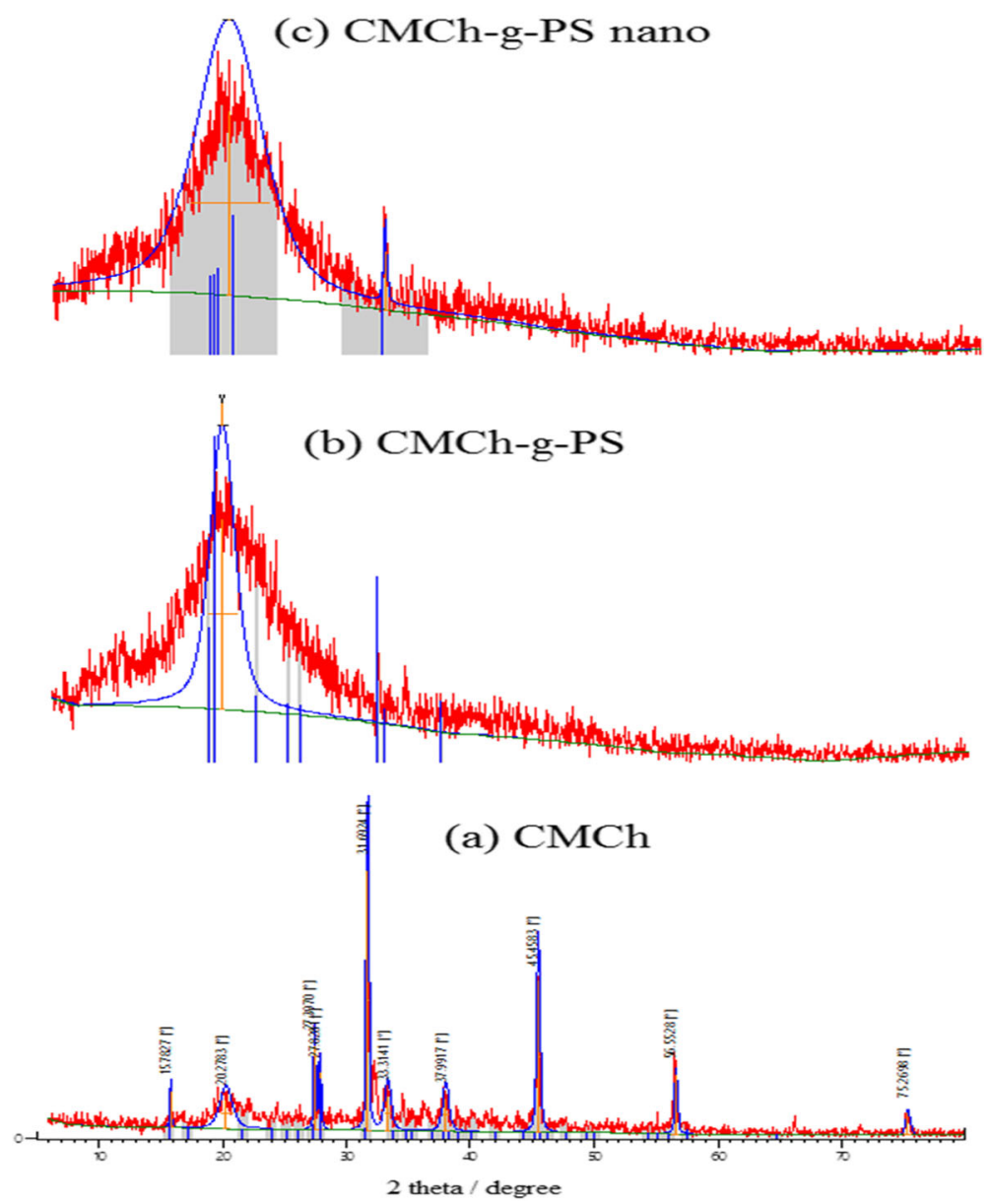

Fig. 6 X-ray diffraction patterns of (a) CMCh, (b) CMCh-g-S, and (c) CMCh-g-S nano at optimum grafting condition

Additionally, the greater styrene concentration, the primary radicals attack the monomer instead of reacting with the backbone polymer. The excess styrene concentration will protect the graft copolymer which might be inhibiting the rate of copolymerization. Hence, 1:3 weight ratio observed to be the optimum concentration in this grafting reaction at $[\mathrm{APS}]=0.6 \mathrm{~g}$ at $60{ }^{\circ} \mathrm{C}$, for $2 \mathrm{~h}[21]$.

\subsubsection{Effect of the reaction temperature}

Grafting was carried out at different temperatures $\left(50-80{ }^{\circ} \mathrm{C}\right)$ and at 1:3 CMCh:styrene weight ratio, while the APS content and reaction time were kept constant (Fig. 3). It was observed that on increasing temperature from 50 to $60{ }^{\circ} \mathrm{C}$, the percentage grafting (G\%) and grafting efficiency (GE\%) increase. Raising the temperature lead to increase the collision between the reactants by lowering the viscosity of the reaction medium with higher mobility of monomer and $\mathrm{CMCh}$ chains. However, increasing the temperature above 60 ${ }^{\circ} \mathrm{C}$ lead to decreasing the $\mathrm{G} \%$ and GE\% probably due to fast decomposition of initiator radicals at high temperature lead to chain transfer reaction, so termination of the growing chains early [2, 25].

\subsubsection{Effect of reaction time}

The effect of reaction time was carried out at constant APS, CMCh:S ratio, and temperature. The percentage grafting increase from 1 to $2 \mathrm{~h}$ and start to decrease; this could be attributable in conformity with increase within number of active sites on the chitosan backbone (Fig. 4). The reduction in $\mathrm{G} \%$ and $\mathrm{GE} \%$ over $3 \mathrm{~h}$ raise homo polymerization of styrene. This could be due according to chains transfer then other aspect reactions [23].

\subsection{Characterization}

\subsubsection{FT-IR}

IR spectra of chitosan (Fig. 5a) presented strong peaks at $1155,1073,1030$, and $895 \mathrm{~cm}^{-1}$ which is related to the saccharide structure. We can notice a very strong broad peak around $3600-3200 \mathrm{~cm}^{-1}$ which corresponds to O$\mathrm{H}$ groups. Also the primary amines present two peaks in this region. Amide I and II appear as two weak peaks at 1653 and $1567 \mathrm{~cm}^{-1}$ respectively. The FTIR spectrum of 


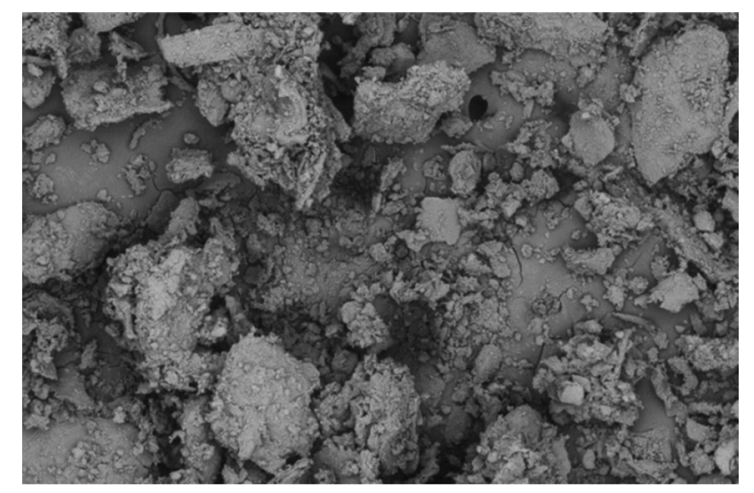

(a)

\section{$\mathrm{CMCh}$}

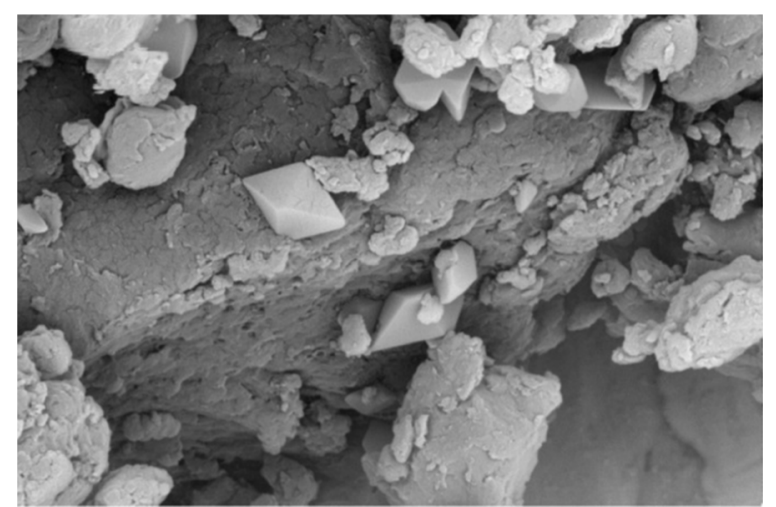

(b)CMCh-g-S

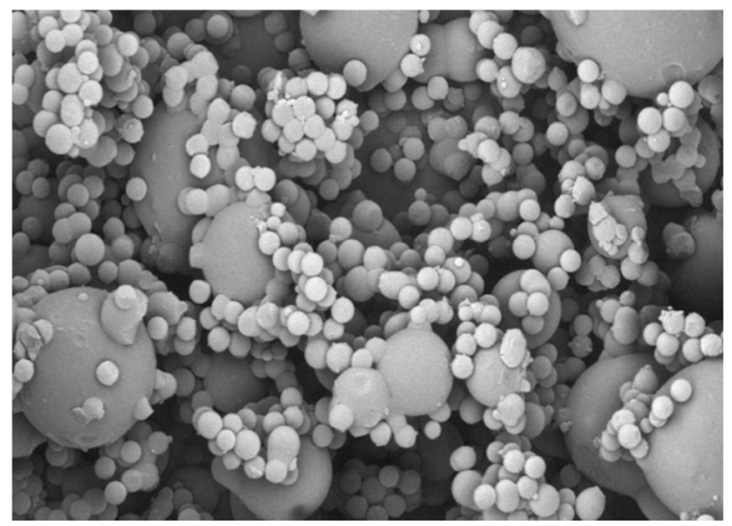

(c)CMCh-g-S nano

Fig. 7 SEM photography of (a) CMCh, (b) CMCh-g-S and (c) CMCh$\mathrm{g}-\mathrm{S}$ nano at optimum grafting conditions

CMCh showed in addition to the aforementioned peaks, a strong peak at $1454 \mathrm{~cm}^{-1}$ which could be assigned to the symmetrical stretching vibration of $\mathrm{COO}^{-}$group. The asymmetrical vibration of $\mathrm{COO}^{-}$group (around $1550 \mathrm{~cm}^{-1}$ ) is overlapped with the deforming vibration of $\mathrm{NH}_{2}$ at $1604 \mathrm{~cm}^{-1}$ to obtain a very strong peak. The $\mathrm{C}-\mathrm{O}$ absorption peak of hydroxyl group became stronger and shifted to $1097 \mathrm{~cm}^{-1}$. The observed results, which are similar to the work $[36,37]$ indicated that

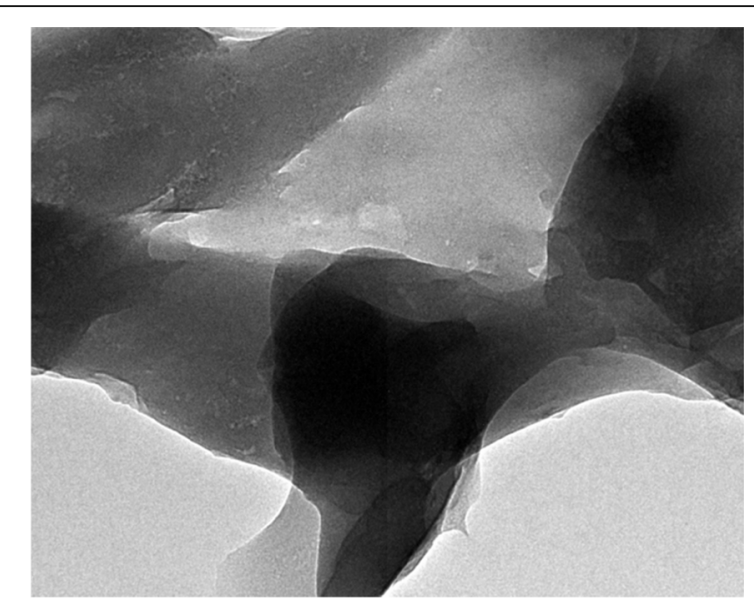

(a) $\mathrm{CMCh}$

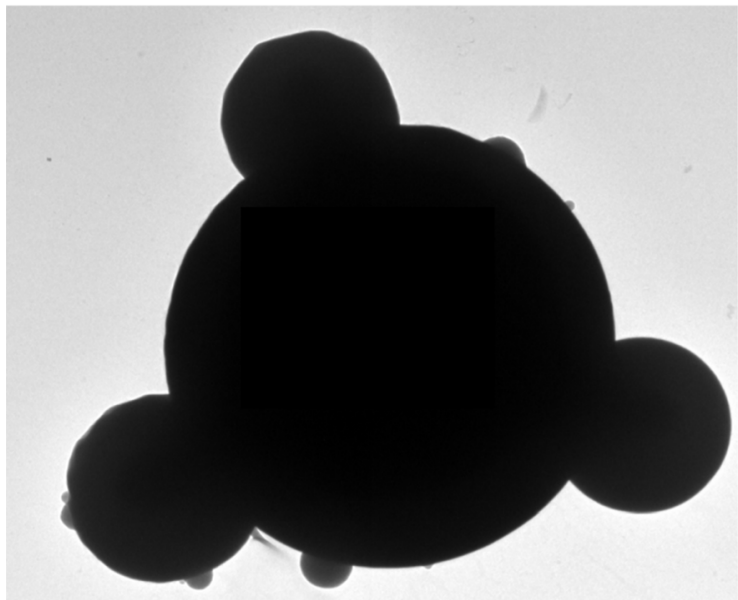

(b)CMCh-g-S

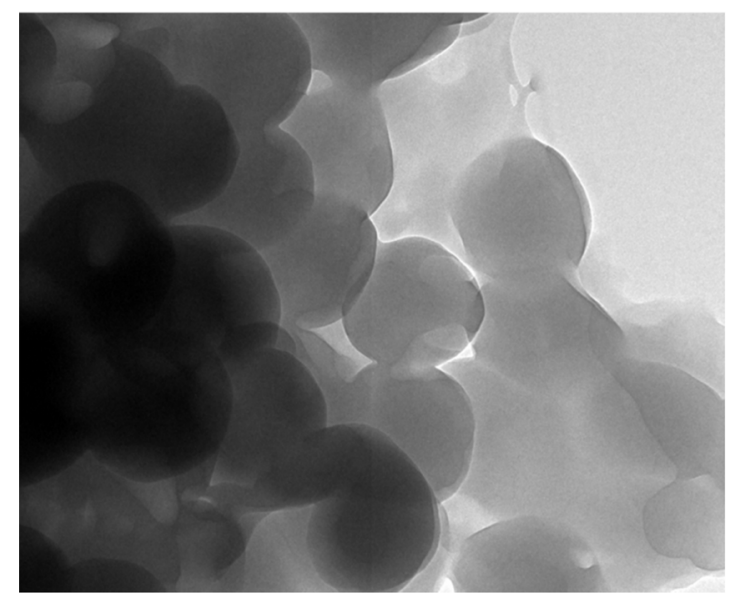

(c)CMCh-g-S nano

Fig. 8 TEM photography of (a) CMCh, (b) CMCh-g-S and (c) CMChg-S nano at optimum grafting conditions 


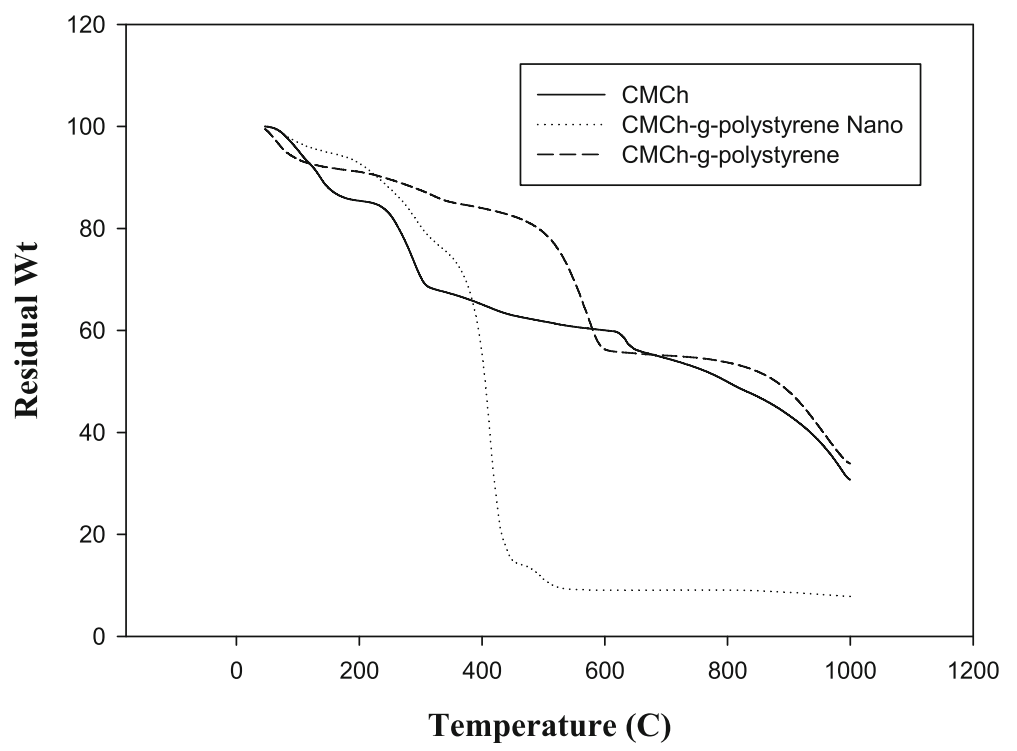

Fig. 9 Thermal analysis of (a) CMCh, (b) CMCh-g-S, and (c) CMCh-g-S nano under $\mathrm{N}_{2}$ atmosphere

substitution was achieved at C6 position (Fig. 5b). FT-IR is an important tool in providing the grafting process. Figure $5 \mathrm{c}$ indicates the presence of styrene peaks with IR band intensities at $3024 \mathrm{~cm}^{-1}$ (aromatic $\mathrm{C}-\mathrm{H}$ stretching); 1600, 1490, 760, $700 \mathrm{~cm}^{-1}$ (aromatic $\mathrm{C}-\mathrm{H}$ bending); 2000-1700 $\mathrm{cm}^{-1}$ (aromatic $\mathrm{C}=\mathrm{C}$ ) in addition to peaks due to $\mathrm{CMCh}$ at $3400-3200 \mathrm{~cm}^{-1}(\mathrm{O}-\mathrm{H}$ and $\mathrm{N}-\mathrm{H}$ stretching) and $1659 \mathrm{~cm}^{-1}$ due to $\mathrm{C}=\mathrm{O}$ stretching (Fig. $5 \mathrm{a}$ ), indicating that styrene has successfully been grafted onto CMCh.

\subsubsection{X-ray diffraction}

CMCh show diffraction peaks around $16.5^{\circ}, 20^{\circ}$, and $36^{\circ}$ and the peaks are weak compared to chitosan which indicate that $\mathrm{CMCh}$ has lower crystallinity than chitosan; this is in agreement with literature [35] (Fig. 6a). For CMCh-g-styrene in macro size and nano size, these peaks disappeared after grafting of $\mathrm{CMCh}$ with styrene. The grafting decreases intensity of the diffraction peaks, which is clearly visible in Fig. 6b, c. The grafted samples showed amorphous nature. The grafting of styrene takes place in a random manner on the carboxymethyl chitosan chain, which affect the crystallinity of the chains and results in formation of amorphous polymer. The values of crystal size confirm the formation of nanoparticles. The average crystal size of $\mathrm{CMCh}$ is about $53.66 \mathrm{~nm}$ while for CMCh-g-styrene is found to be $1.44 \mathrm{~nm}$.

\subsubsection{Scanning and transmission electron microscopes}

The scanning electron microscope (SEM) of CMCh, $\mathrm{CMCh}$-g-styrene, and $\mathrm{CMCh}$-g-styrene nanoparticles is shown in Fig. 7a-c. Graft polymerization of CMCh affected the surface morphology. It was found that the surface appearances were drastically changed upon grafting as compared with the surface of CMCh which is smooth and free of any particles, whereas the surfaces of the grafted samples appeared covered with a new reaction product which resulted from grafting process. It

Table 1 Antibacterial activity of CMCh, CMCh-g-S and CMCh-g-S nano

\begin{tabular}{|c|c|c|c|c|c|c|}
\hline \multirow[t]{4}{*}{ Samples } & \multicolumn{6}{|c|}{ Tested microorganisms } \\
\hline & \multicolumn{4}{|c|}{ Gram positive bacteria } & \multirow{2}{*}{\multicolumn{2}{|c|}{$\begin{array}{l}\text { Gram negative bacteria } \\
\text { E. coli (RCMB 010052) }\end{array}$}} \\
\hline & \multicolumn{2}{|c|}{ S. aureus (RCMB 010028) } & \multicolumn{2}{|c|}{ S. pneumoniae (RCMB 010010) } & & \\
\hline & $\begin{array}{l}\text { Inhibition } \\
\text { zone(mm) }\end{array}$ & $\begin{array}{l}\text { Minimum inhibitory } \\
\text { concentration (MIC) }(\mu \mathrm{g} / \mathrm{mL})\end{array}$ & $\begin{array}{l}\text { Inhibition } \\
\text { zone (mm) }\end{array}$ & $\begin{array}{l}\text { Minimum inhibitory } \\
\text { concentration (MIC) }(\mu \mathrm{g} / \mathrm{L})\end{array}$ & $\begin{array}{l}\text { Inhibition } \\
\text { zone (mm) }\end{array}$ & $\begin{array}{l}\text { Minimum inhibitory } \\
\text { concentration (MIC) }(\mu \mathrm{g} / \mathrm{mL})\end{array}$ \\
\hline CMCh & $13.3 \pm 0.3$ & 520.0 & $10.1 \pm 0.3$ & 525.0 & $8.2 \pm 0.7$ & 527.0 \\
\hline CMCh-g-S & $16.1 \pm 0.1$ & 3.9 & $18.1 \pm 0.72$ & 1.95 & $14.6 \pm 0.3$ & 33.0 \\
\hline $\begin{array}{l}\text { CMCh-g-S } \\
\text { nano }\end{array}$ & $21.1 \pm 0.2$ & 1.95 & $21.8 \pm 0.53$ & 0.98 & $14.0 \pm 0.2$ & 45.0 \\
\hline Ampicillin & $27.4 \pm 0.72$ & 0.49 & $23.8 \pm 1.2$ & 0.98 & & \\
\hline Ciprofloxacin & & & & & $23.4 \pm 0.63$ & 0.98 \\
\hline
\end{tabular}


Table 2 Antifungal activity of CMCh, CMCh-g-S and CMCh-g-S nano

\begin{tabular}{|c|c|c|c|c|c|c|c|c|}
\hline \multirow[t]{3}{*}{ Samples } & \multicolumn{8}{|c|}{ Tested microorganisms } \\
\hline & \multicolumn{2}{|c|}{ A. fumigates (RCMB 02568) } & \multicolumn{2}{|c|}{ G. candidum (RCMB 05097) } & \multicolumn{2}{|c|}{ C. albicans (RCMB 05036) } & \multicolumn{2}{|c|}{ S. racemosum (RCMB 05922) } \\
\hline & $\begin{array}{l}\text { Inhibition } \\
\text { zone(mm) }\end{array}$ & $\begin{array}{l}\text { Minimum inhibitory } \\
\text { concentration (MIC) } \\
(\mu \mathrm{g} / \mathrm{ml})\end{array}$ & $\begin{array}{l}\text { Inhibition } \\
\text { zone(mm) }\end{array}$ & $\begin{array}{l}\text { Minimum inhibitory } \\
\text { concentration (MIC) } \\
(\mu \mathrm{g} / \mathrm{ml})\end{array}$ & $\begin{array}{l}\text { Inhibition } \\
\text { zone } \\
(\mathrm{mm})\end{array}$ & $\begin{array}{l}\text { Minimum inhibitory } \\
\text { concentration (MIC) } \\
(\mu \mathrm{g} / \mathrm{ml})\end{array}$ & $\begin{array}{l}\text { Inhibition } \\
\text { zone(mm) }\end{array}$ & $\begin{array}{l}\text { Minimum inhibitory } \\
\text { concentration (MIC) } \\
(\mu \mathrm{g} / \mathrm{ml})\end{array}$ \\
\hline$\overline{C M C h}$ & $12.1 \pm 0.5$ & 550 & $9.3 \pm 0.3$ & 540 & $5.4 \pm 0.5$ & 555 & $7.3 \pm 0.3$ & 454 \\
\hline CMCh-g-S & $18.3 \pm 0.3$ & 3.9 & $\begin{array}{l}17.3 \pm \\
0.53\end{array}$ & 15.63 & $\begin{array}{l}17.2 \pm \\
0.53\end{array}$ & 15.63 & $\begin{array}{l}18.1 \pm \\
0.63\end{array}$ & 3.9 \\
\hline $\begin{array}{l}\text { CMCh-g-S } \\
\text { nano }\end{array}$ & $\begin{array}{l}20.9 \pm \\
0.53\end{array}$ & 1.95 & $20.8 \pm 1.5$ & 1.95 & $\begin{array}{l}19.8 \pm \\
0.63\end{array}$ & 3.9 & $21.3 \pm 1.2$ & 1.95 \\
\hline $\begin{array}{l}\text { Amphotericin } \\
\text { B }\end{array}$ & $23.7 \pm 1.2$ & 0.98 & $\begin{array}{l}26.7 \pm \\
0.58\end{array}$ & 0.49 & $\begin{array}{l}25.4 \pm \\
0.54\end{array}$ & 0.49 & $22.5 \pm 1.2$ & 0.98 \\
\hline
\end{tabular}

seem that the particles looked spherical and the backbone of CMCh is covered with styrene. SEM can be used as an evidence of grafting process. Also, the SEM images of CMCh-g-styrene differ from that of CMCh-g-styrene nanoparticles as the shape and size of particles changed.

TEM images also confirm the formation of CMCh-gstyrene and $\mathrm{CMCh}$-g-styrene nanoparticles (Fig. 8a-c). CMCh-g-styrene particles look spherical (Fig. 8b) while nanoparticles seems to be agglomerated (Fig. 8c). The particle size also changed as shown on images.

\subsubsection{Thermal analysis}

Pure CMCh showed loss of weight attributed to the decomposition of the polymer starting from 279.12 to $600{ }^{\circ} \mathrm{C}$. For $\mathrm{CMCh}$-g-styrene and $\mathrm{CMCh}$-g-styrene nanoparticles, the loss of weight appears in the TG response from 548.78 to $600{ }^{\circ} \mathrm{C}$ and from 365.35 to $500{ }^{\circ} \mathrm{C}$ respectively (Fig. 9). These TG data showed some decrease of thermal stability of CMCh-g-styrene nanoparticles compared to pure $\mathrm{CMCh}$ which can be related to some disruption of the crystalline structure of CMCh.

\subsection{Antimicrobial activity \\ 5.3.1 Antibacterial activity}

The recent CMCh graft in macro and nano size showed in vitro antibacterial activity against the examined bacteria. The results of antibacterial activity concerning the $\mathrm{CMCh}$ and grafted $\mathrm{CMCh}$ using diffusion agar method are listed in Table 1.Compared with $\mathrm{CMCh}$, all the grafted $\mathrm{CMCh}$ in each sizes showed a higher antibacterial activity. Many mechanisms concerning chitosan antimicrobial activity have been assumed. The most suitable one is the reaction between (+ve) charged chitosan molecules and (-ve) charged microbial cell membrane. The interaction is occurred by the electrostatic forces within the protonated $\mathrm{NH}_{3}{ }^{+}$groups of chitosan and the electronegative charges regarding the microbial cell surface. This electrostatic interaction effects in twofold interferences: (1) through promoting modifications in the properties of membrane wall permeability, consequently provoke inner osmotic imbalances consequently inhibit the growth of the microorganisms, and (2) by means of the hydrolysis concerning the peptidoglycans in the microorganism wall, leading to the loss of intracellular electrolytes such as potassium ions, then other low molecular weight proteinaceous constituents (e.g., protein, nucleic acid, glucose, and lactate dehydrogenase) [15]. Since the mechanism basically depends on electrostatic interaction, it is clear that the higher the wide variety concerning cationized amines, the higher will be the antimicrobial activity. Carboxymethylation of chitosan allowed the adjustment of CMCh including higher hydrophilicity, including better solubility of aqueous media or including greater positive density, where $\mathrm{CMCh}$ of the $-\mathrm{COOH}$ groups may react along the $-\mathrm{NH}_{2}$ groups and modified these $-\mathrm{NH}_{2}$ groups into $-\mathrm{NH}_{3}{ }^{+}$ groups leading to accelerated polycationic character (non$\mathrm{pH}$ dependent high quality charges about $\mathrm{CMCh}$ ). Further, the introduction of styrene monomer onto $\mathrm{CMCh}$ with the aid of grafting increases the bacterial activity. A suggested mechanism proposed that the binding regarding chitosan with microbial DNA, which leads to the inhibition of the mRNA then protein synthesis with the aid of entrance of chitosan in the nuclei concerning the microorganisms [17]. The third mechanism is the chelating of metals, suppression concerning spore factors and binding to fundamental nutrients to microbial increase [11]. Moreover, CMCh-g-S in macro or nano size stability showed greater antibacterial activity against the Gram-positive bacteria than against the Gram-negative bacteria (Table 1). As CMCh-g-S among macro size caused inhibition zone diameter of S. pneumonia and S. aureus of $18.1 \pm$ 0.72 , longevity and $16.1 \pm 0.58 \mathrm{~mm}$, respectively, corresponded to $10.4 \pm 0.2 \mathrm{~mm}$ of $E$. coli (Table 1). This may additionally be attributed in accordance with their exceptional cell wall. The cell wall of Gram-positive bacteria is utterly made of peptide polyglycogen. The peptidoglycan layer is composed of networks together with lots of pores, which permit foreign molecules to come in the cell without difficulty and allows greater rapid attention regarding 


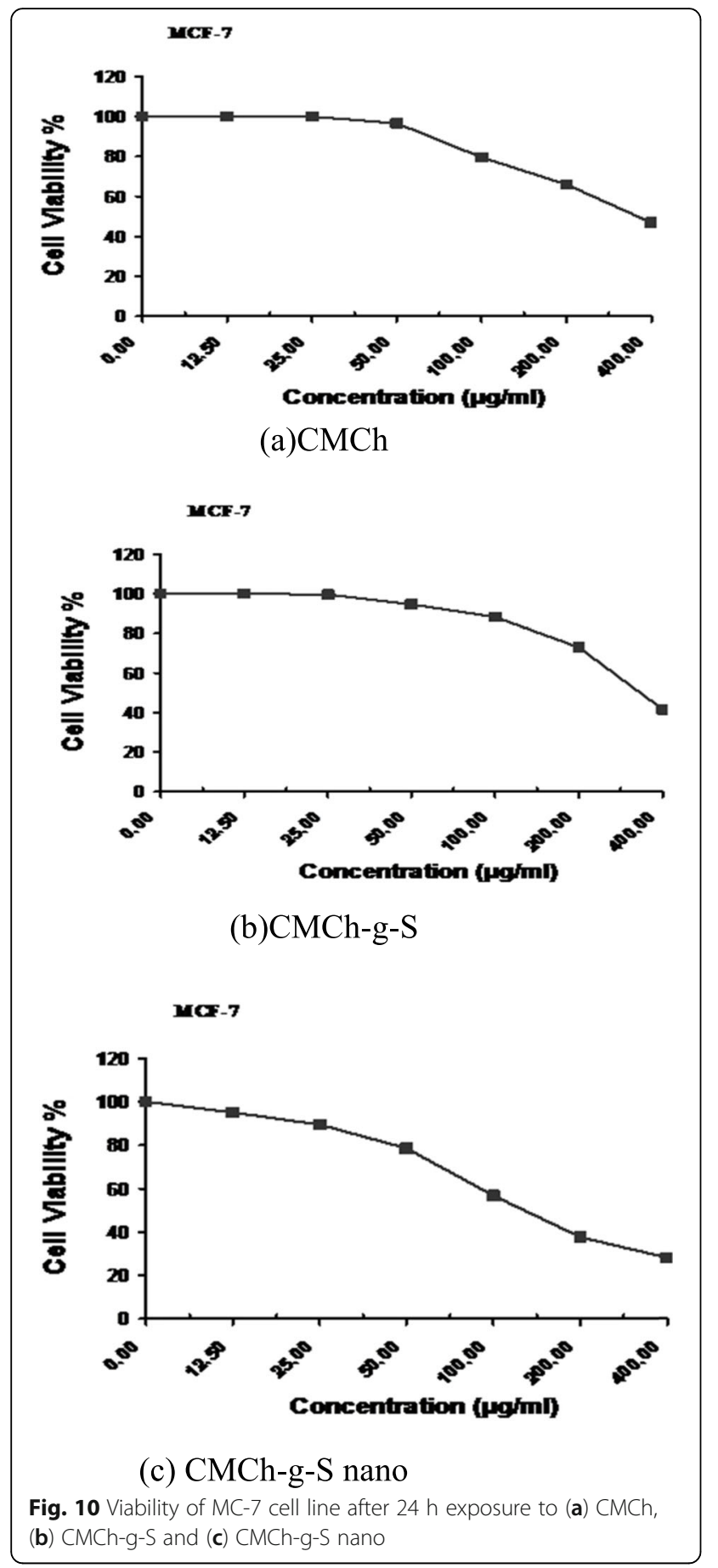

ions among the cell. But the mobile wall of Gramnegative microorganism is performed on regarding a thin membrane of peptide polyglycogen and an outer membrane constituted of durability lipopoly saccharide, lipoprotein, and phospholipids. Because of the difficult bilayer cell structure, the outer membrane is a dynamic barrier against foreign molecules with high molecular weight. Therefore, the new substances have distinctive results about the two sorts regarding
Table 3 Cytotoxicity effect of CMCh, CMCh-g-S and CMCh-g-S nano against $\mathrm{MCH}-7$ cell line

\begin{tabular}{llll}
\hline Concentration & \multicolumn{2}{l}{ Viability \% } \\
\cline { 2 - 4 } & CMCh & CMCh-g-S & CMCh-g-S nano \\
\hline 0 & 100 & 100 & 100 \\
12.5 & 100 & 100 & 95.06 \\
25 & 100 & 99.56 & 89.41 \\
50 & 96.63 & 94.63 & 78.56 \\
100 & 79.56 & 88.16 & 56.81 \\
200 & 65.94 & 72.97 & 37.72 \\
400 & 46.88 & 41.63 & 28.13 \\
IC 50 & $367 \mu \mathrm{g} / \mathrm{mL}$ & $347 \mu \mathrm{g} / \mathrm{mL}$ & $136 \mu \mathrm{g} / \mathrm{mL}$ \\
\hline
\end{tabular}

bacteria. An extra proof is because the increased activity of grafted CMCh toward Gram-positive bacteria than that against Gram-negative bacteria comes from their minimal inhibitory attention (MIC) values. MIC is described as much the lowest concentration concerning an antimicrobial that will break the visible increase of a microorganism since overnight incubation. The MIC values on durability grafted CMCh toward $S$. pneumonia and S. aureus were shown in Table 1 . It worth mentioning that the antibacterial activity of CMCh-g-S nano size toward S. pneumoniae is nearly equal after that of the standard drug Ampicillin. It is evident that the graft $\mathrm{CMCh}$ within nano size exhibit higher bacterial than the grafting $\mathrm{CMCh}$ within macro size. A larger surface area (as in action of nanoparticles) ensures an multiplied range of probable interaction including bio-organics current on the viable cell surface [29].

\subsubsection{Antifungal activity}

The antifungal activities of $\mathrm{CMCh}$ and $\mathrm{CMCh}-\mathrm{g}-\mathrm{S}$ in macro and nano size against $A$. fumigatus (RCMB 02568), G. candidum (RCMB 05097), S. racemosum (RCMB 05922), and C. albicans (RCMB 05031) are shown within Table 2. The results show that grafted CMCh had effective activities toward the tested fungi, compared with parent $\mathrm{CMCh}$, together with inhibitory indices ranging from $21.3 \pm 0.2$ to $17.2 \pm 0.53 \mathrm{~mm}$ inhibition zone (Table 2) and with MIC values ranging from 1.95 up to $15.63 \mu \mathrm{g} / \mathrm{mL}$.

Generally, chitosan has been stated as being very effective in inhibiting spore germination, germ tube tension, and radial growth [12]. The antifungic mechanism of chitosan includes every wall morphogenesis with chitosan molecules interfering directly with fungal growth, in a similar way to the effects observed in bacteria cells. 


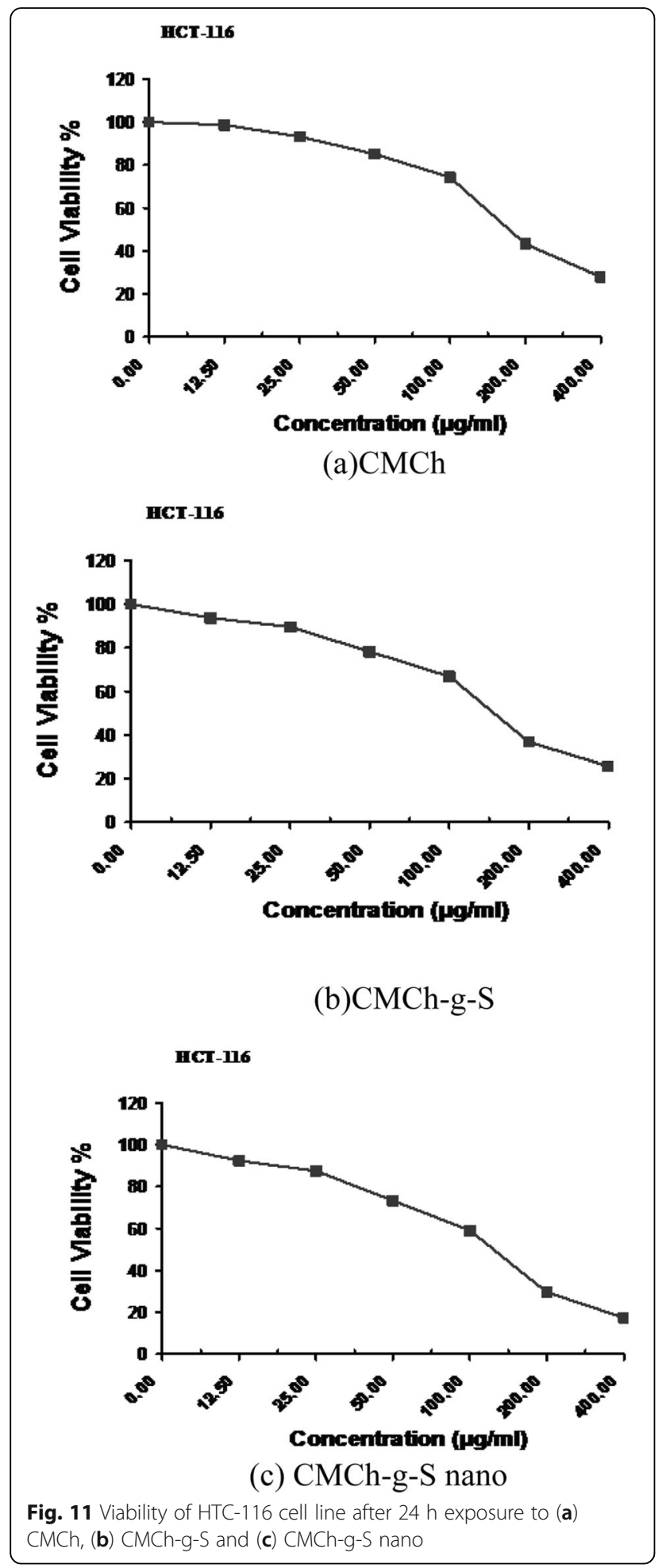

The microscopic observation reported that chitosan molecules diffuse inside hyphae interfering on the enzymes exercise responsible for the fungus growth [13].

Again, the results additionally display how the antifungal activities are affected by the size of the organized graft
Table 4 Cytotoxicity effect of CMCh, CMCh-g-S and CMCh-g-S nano against HTC-116 cell line

\begin{tabular}{llll}
\hline Concentration & \multicolumn{2}{l}{ Viability $\%$} & \\
\cline { 2 - 4 } & CMCh & CMCh-g-S & CMCh-g-S nano \\
\hline 0 & 100 & 100 & 100 \\
12.5 & 98.64 & 93.67 & 92.36 \\
25 & 93.18 & 89.54 & 87.45 \\
50 & 85.06 & 78.19 & 73.28 \\
100 & 74.25 & 66.82 & 58.96 \\
200 & 43.16 & 36.75 & 29.67 \\
400 & 27.93 & 25.64 & 17.48 \\
IC 50 & $178 \mu \mathrm{g} / \mathrm{mL}$ & $156 \mu \mathrm{g} / \mathrm{mL}$ & $131 \mu \mathrm{g} / \mathrm{mL}$ \\
\hline
\end{tabular}

CMCh. Thus, while the CMCh-g-S nanoparticles show greater inhibition area diameter and decrease MIC values relative to the grafted CMCh Macro particles (Table 2).

\subsection{Cytotoxicity}

The potent cytotoxicity of whole synthesized compounds toward the human breast cancer (MCF-7) and colon carcinoma (HCT-116) cell lines was evaluated in vitro using crystal violet assay. The dose-response curves introduced within (Figs. 10 and Fig. 11a-c) point out that all compounds reduced MCF-7 and HCT-116 cells viability. Generally, the results showed that increasing the concentration of the compounds led to significant reduction of cell viability for the two examined cell lines. For breast cancer (MCF-7), parent $\mathrm{CMCh}$ was discovered to be the highest active compound, since its highest concentration $(400 \mu \mathrm{g} /$ $\mathrm{mL}$ ) showed the highest decrease in the percentage of cell viability (Table 3, Fig. 10a). Also, IC50 values proved that $\mathrm{CMCh}$ was the highest active compound against MCF-7 cells (IC50 = 136) while CMCh-g-S was the lowest active compound against MCF-7 cells $(\mathrm{IC50}=367 \mu \mathrm{g} / \mathrm{mL})$. The effect of CMCh and toughness CMCh-g-S macro and nanoparticles on HCT116 cells is showed in Fig. 11a-c (Table 4). CMCh also is the highest active compound with IC50 $=131 \mu \mathrm{g} / \mathrm{mL}$ compared to that for CMCh IC50 $=178 \mu \mathrm{g} / \mathrm{mL}$.

\section{Conclusion}

New antimicrobial materials were successfully prepared by grafting styrene onto carboxymethyl chitosan backbone using ammonium persulfate as initiator which are confirmed by the analytical techniques used. The optimum grafting parameters were found to be at $1: 3 \mathrm{CMCh}$ :styrene weight ratio, $60^{\circ} \mathrm{C}$ with $0.6 \mathrm{~g}$ APS and $2 \mathrm{~h}$ reaction time. The grafted CMCh successfully prepared in nano scale. The disruption of the 


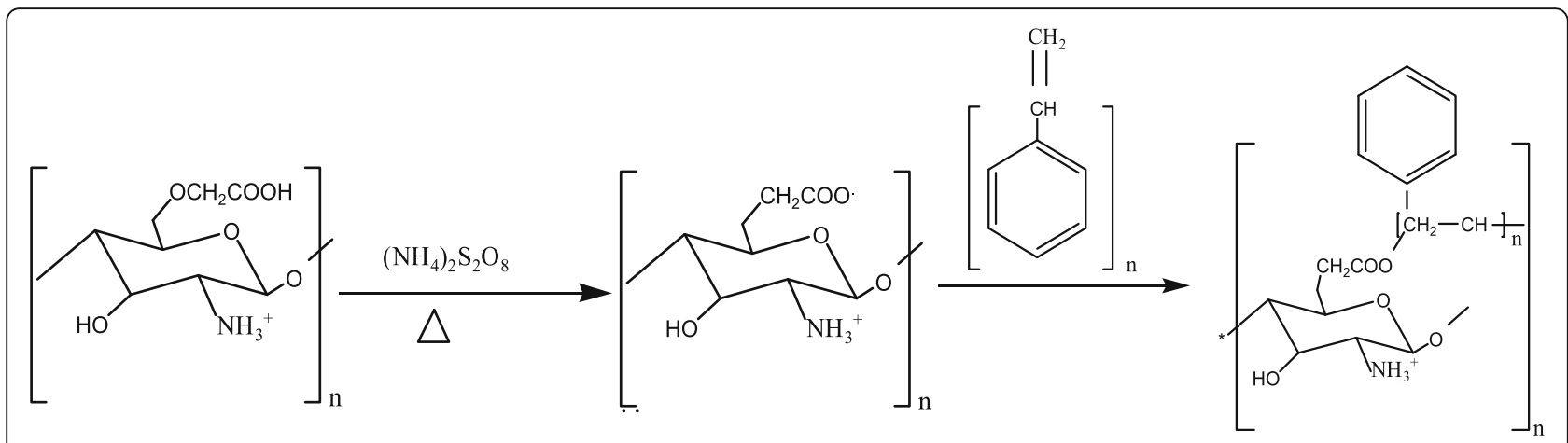

Scheme 2 Grafting of styrene onto carboxymethyl chitosan

crystalline structure of the new materials leads to decrease in the thermal stability than $\mathrm{CMCh}$. The current study reflects that the CMCh-g-S in both scales bear a promising potential to be used as antimicrobial agent. However, The new materials show lower activity against MCF-7 and HTC-116 cell lines than CMCh, so it is recommended to apply the new materials as antimicrobial agents. In future study, an attempt will be made to modify the grafting substances to be used effectively in medical field.

\section{Abbreviations}

APS: Ammonium persulfate; CMCh: Carboxymethyl chitosan; DMSO: Dimethyl sulfoxide; MIC: Minimum inhibitory concentration; O-CMCh: Oxygencarboxymethyl chitosan; PS: Poly styrene; S: Styrene

\section{Acknowledgments}

Not applicable.

\section{Authors' contributions}

All data analyzed and interpreted by the corresponding author.

\section{Funding}

This work was supported by Support and Project Finance Office, Beni Suef University.

\section{Availability of data and materials}

All data is provided in full in the results section of this paper.

\section{Ethics approval and consent to participate}

Not applicable.

\section{Consent for publication}

Not applicable.

\section{Competing interests}

The authors declare that they have no competing interests.

Received: 31 July 2019 Accepted: 15 October 2019

Published online: 16 January 2020

\section{References}

1. Abu Naim A, Abdulganiyu U, Mohd M (2014) Synthesis and characterization of chitosan grafted with polystyrene using ammonium persulfate initiator. Material. Lett 124:12-14. https://doi.org/10.1016/j.matlet.2014.03.007

2. Abu Naim A, Umar A, Sanagi MM, Basaruddin N (2013) Chemical modification of chitin by grafting with polystyrene using ammonium persulfate initiator. Carbohydr Polym 98:1618-1623. https://doi.org/10.1016/j. carbpol.2013.07.054

3. Allcock H, Lampe F, \& Mark J. 2003. Contemporary polymer chemistry. Upper Saddle River, N.J.: Pearson Education/Prentice Hall.
4. Arvanitoyannis I. Totally and partially biodegradable polymer blends based on natural and synthe tic macromole cule s: prepar ation, physical properties, and potential as food packaging materials. J Macromol Sci R M C,1999;39:205 - 271. doi.org/https://doi.org/10.1081/MC-100101420.

5. Arvanitoyannis I, Nakayama A, Aiba S (1998) Chitosan and gelatin based edible films: state diagrams, mechanical and permeation properties Carbohyd. Polym 37:371-382. https://doi.org/10.1016/s0144-8617(98)00083-6

6. Assis OBG, Bernardes Filho R, Viera DC, Campana Filho SP (2002) Characterization of chitosan self-assembled films. Int J Polymer Mater 51: 633-638. https://doi.org/10.1080/714975800

7. Assis OBG, Pessoa JDC (2004) Preparation of thin films of chitosan for use as edible coatings to inhibit fungal growth on sliced fruits. Braz J Food Technol. 7:17-22

8. Assis, O. B. G. \& Silva, V. L. (2003): Caracterização Estrutural e da Capacidade de Absorção de Áqua em Filmes Finos de Quitosana Processados em Diversas Concentrações Polmeros: Ciência \& Tecnologia, 13,p.223-228. doi. org/https://doi.org/10.1590/S0104-14282003000400006

9. Britto, D.; Campana Filho, S. P. \& Assis, O. B. G. (2005): Mechanical properties of N, N, N-trimethylchitosan chloride films. Polimeros: Ciência \& Tecnologia, 15, p.129-132. doi.org/10.1016/j.ijbiomac.2007.02.005

10. Chen X, Park H. Chemical characteristics of O-carboxymethyl chitosans related to the preparation conditions. Carbohyd. Polym. 2003; 53:355-359. doi.org/https://doi.org/10.1016/S0144-8617(03)00051-1.

11. Cuero R, Osuji G, Washington A (1991) N-carboxymethyl chtosan inhibition of alpha-toxin production: role of zinc. Biotechnol Lett 13:441-444. https:// doi.org/10.1007/BF01030998

12. El-Ghaouth A, Arul J, Grenier J, Asselin A (1992C) Antifungal activity of chitosan on two postharvest pathogens of strawberry fruits. Phytopathology 82:398-402. https://doi.org/10.1094/Phyto-82-398

13. Eweis M, ElKholy S, EISabaa M (2006) Antifungal efficacy of chitosan and its thiourea derivatives upon the growth of some sugar-beet pathogens. Int J Biol Macromol 38:1-8. https://doi.org/10.1016/j.ijbiomac.2005.12.009

14. Fan L, Du Y, Zhang B, Yang J, Zhou J, Kennedy J (2006) Preparation and properties of alginate/carboxymethyl chitosan blend fibers. Carbohyd. Polym 65:447-452. https://doi.org/10.1016/j.carbpol.2006.01.031

15. Feng Q, Wu J, Chen G, Cui F, Kim T, Kim J. A mechanistic study of the antibacterial effect of silver ions on Escherichia coli and Staphylococcus aureus J Biomed Mater Res. 2000; 52:662-668. doi.org/https://doi.org/10. 1002/1097-4636(20001215)52:4<662:*aid-jbm10>3.0.CO:2-3.

16. Gomha S, Riyagh S, Mahmmoud E, Elaasser M (2015) Synthesis and anticancer activities of thiazoles, 1,3-thiazines and thiazolidine using chitosan-grafted-poly(vinylpyridine) as basic catalyst. Heterocycles 91(6): 1227-1243. https://doi.org/10.1007/s10593-016-1815-9

17. Hadwiger L, Kendra D, Fristensky B, Wagoner W, Muzzarelli RAA, Jeuniaux C, Gooday CW (1986) Chitin in nature and technology. Plenum Press, New York, pp 209-214

18. Haque T, Chen H, Ouyang W, Martoni C, Lawuyi B, Urbanska A, Prakash S (2005) Superior cell delivery features of poly(ethylene glycol) incorporated alginate, chitosan, and poly-L-lysine microcapsule. Mol. Pharmaceut 2:29-36. https://doi.org/10.1021/mp049901v

19. Jayakumar R, Chennazhi K, Muzzarelli R, Tamura H, Nair S, Selva-murugan N (2010a) Chitosan conjugated DNA nanoparticles in gene therapy. Carbohyd. Polym 79:1-8. https://doi.org/10.1201/EBK1439816035-c26 
20. Jayakumar R, Prabaharan M, Nair S, Tokura S, Tamura H, Selvamurugan N (2010b) Novel carboxymethyl derivatives of chitin and chitosan materials and their biomedical applications. Prog. Mater. Sci 55:675-709. https://doi. org/10.1016/j.pmatsci.2010.03.001

21. Joshi J, Sinha V (2007) Ceric ammonium nitrate induced grafting of polyacrylamide onto carboxymethyl chitosan. Carbohyd. Polym 67:427-435. https://doi.org/10.1016/j.carbpol.2006.06.021

22. Kaczmarek H, Swiatek M, Kaminska A (2004) Modification of polystyrene and poly(vinyl chloride) for the purpose of obtaining packaging materials degradable in the natural environment. Polym. Degrad 83:35-45. https://doi. org/10.1016/S0141-3910(03)00202-7

23. Kaewtatip K, Tanrattanakul V (2008) Preparation of cassava starch grafted with polystyrene by suspension polymerization. Carbohyd. Polym 73(4):647655. https://doi.org/10.1016/j.carbpol.2008.01.006

24. Kim H, Chen F, Wang X, Rajapakse N. Effect of chitosan on the biological properties of sweet basil (Ocimum basilicumL.) J. Agr. Food Chem. 2005; 53 : 3696 -3701. doi.org/https://doi.org/10.1021/jf0480804.

25. Matyjaszewski K, Patten T, Xia J. Controlled /"Living" radical polymerization. Kinet Homog Atom Transf Rad Polymerization Styr. 1997; 35:674-680. doi. org/https://doi.org/10.1021/ja963361g.

26. Mohamed R, Sabaa M (2010) Graft copolymerization of acrylonitrile and its amidoxime derivatives onto chitosan. J Appl Polym Sci 116:413-421. https:// doi.org/10.1002/app.31254

27. Mosmann T. Rapid colorimetric assay for cellular growth and survival: application to proliferation and cytotoxicity assays J Immunol Methods. 1983; 65: 55-63. doi.org/https://doi.org/10.1016/0022-1759(83)90303-4.

28. Muzzarelli R, Ramos V, Stanic V, Dubini B, Mattioli-Belmonte M, Tosi G et al (1998) Osteogenesis promoted by calcium phosphate N, N-dicarboxymethyl chitosan. Carbohyd. Polym 36:267-276. https://doi.org/10.1016/s01448617(98)00008-3

29. Rizwan W, Young-Soon K, Amrita M, Sh H-S (2010) Formation of ZnOmicroflowers prepared via solution process and their antibacterial activity. J Nanoscale Res Lett 5(10):1675-1681. https://doi.org/10.1007/s11671-0109694-y

30. Roberts GAF (1992) Chitin Chemistry. MacMillan Press, London, p 350

31. Sabaa M, Mohamed N, Mohamed R, Khalil N, Abd El Latif S (2010) Synthesis, characterization and antimicrobial activity of poly ( $\mathrm{N}$-vinyl imidazole) grafted carboxymethyl chitosan. Carbohyd. Polym 79:998-1005. https://doi.org/10. 1016/j.carbpol.2009.10.024

32. Sheikh N, Akhavan A, Ataeivarjovi E (2013) Radiation grafting of styrene on starch with high efficiency. Rad Phys Chem 85:189-192. https://doi.org/10. 1016/j.radphyschem.2012.10.005

33. Sun L, Du Y, Fan L, Chen X, Yang J (2006) Preparation, characterization and antimicrobial activity of quaternized carboxymethyl chitosan and application as pulp-cap. Polymers 47:1796-1804. https://doi.org/10.1016/j. polymer.2006.01.073

34. Tikhonov V, Stepnova E, Babak V, Yamskov I, Palma-Guerrero J, Jansson H, Lopez-Llorca L, Salinas J, Gerasimenko D, Avdienko I, Varlamov V (2006) Bactericidal and antifungal activities of a low molecular weight chitosan and its N-/2(3)-(dodec-2-enyl)succinoyl/-derivatives. Carbohyd Polym 64:6672. https://doi.org/10.1016/j.carbpol.2005.10.021

35. Tripathi S, Mehrotra G, Dutta P (2009) Physicochemical and bioactivity of cross-linked chitosan-PVA film for food packaging applications. Int J Bio Macromol 45:372-376. https://doi.org/10.1016/j.ijbiomac.2009.07.006

36. Xie W, Xu X, Wang W, Liu Q (2002a) Preparation of water- soluble chitosan derivatives and their antibacterial activity. J App Polym Sci 85:1357-1361. https://doi.org/10.1002/app.10424

37. Xie W, Xu X, Wang W, Liu Q (2002b) Preparation and antibacterial activity of a water-soluble chitosan derivative. Carbohyd Polym 50(1):35-40. https:// doi.org/10.1016/S0144-8617(01)00370-8

38. Yamada K, Akiba Y, Shibuya T, Kashiwada A, Matsuda K, Hirata M (2005) Water purification through bioconversion of phenol compounds by tyrosinase and chemical adsorption by chitosan beads. Biotechnol Prog 21: 823-829. https://doi.org/10.1021/bp0495668

\section{Publisher's Note}

Springer Nature remains neutral with regard to jurisdictional claims in published maps and institutional affiliations.

\section{Submit your manuscript to a SpringerOpen ${ }^{\circ}$ journal and benefit from:}

- Convenient online submission

- Rigorous peer review

- Open access: articles freely available online

High visibility within the field

- Retaining the copyright to your article

Submit your next manuscript at $\boldsymbol{\nabla}$ springeropen.com 